\title{
HIV integration and T cell death: additional commentary
}

\author{
Arik Cooper ${ }^{1}$, Mayra García ${ }^{1}$, Constantinos Petrovas ${ }^{2}$, Takuya Yamamoto², Richard A Koup ${ }^{2}$ and Gary J Nabel ${ }^{1,3^{*}}$
}

\begin{abstract}
Estaquier et al. provide commentary on our paper that elucidated the mechanism by which HIV-1 causes cell death in activated CD4 T lymphocytes. We showed that proviral DNA integration triggers DNA-PK dependent death signaling, leading to p53 phosphorylation and cell demise (Cooper A et al. Nature 498:376-379, 2013). They have raised several hypothetical points that we further clarify here.
\end{abstract}

1. In their commentary, the authors note that cell death in our study was observed only in cells lacking p24 antigen expression (p24) and argue that a mechanism in which integration triggers death would lead to cell killing before the virus had a chance to replicate in its target cell.

Response: Estaquier et al. provide no data to support their claim that cell death is immediate, and none was suggested in the paper. In our study, we showed that viral gene expression can be detected prior to the onset of cell death using a GFP reporter gene. Thus, we noted that dying $\mathrm{p} 24^{-}$cells originate from productively infected cells that express viral genes before they lose expression, which is concomitant with cell death (Figure two c in ref. [1]). The explanation for the loss of viral proteins upon cell death is unknown but may result from activation of cellular proteases that degrade them or from epigenetic downregulation. This finding explains why death is observed only in p24- cells and indicates that the virus productively infects its host cell prior to inducing death, a notion reinforced by the observed viral spread in primary cultures infected with a replication-competent HIV-1 (Figure one $\mathrm{c}$ in ref. [1]). We found that productively infected cells die within 2 to 4 days after infection

\footnotetext{
* Correspondence: Gary.Nabel@sanofi.com

'Virology Laboratory, Vaccine Research Center, National Institute for Allergy and Infectious Diseases, National Institutes of Health, Bldg. 40, Room 4502, MSC-3005, 40 Convent Drive, Bethesda, MD 20892-3005, USA

${ }^{3}$ Current address: Sanofi, 640 Memorial Drive, Cambridge, MA 02139, USA
}

Full list of author information is available at the end of the article in vitro and within 3 days ex vivo, consistent with the in vivo half-life of CD4 lymphocytes in humans infected with HIV-1 and in macaques infected with SIV $[2,3]$. Given that HIV-1 integrates its cDNA within 24 hours following infection [4,5], the onset of cell death is relatively delayed, possibly as a result of anti-apoptotic activities of host and viral machineries [6-8], allowing HIV-1 sufficient time to complete its replication cycle. The DNAPK-p53 death pathway is therefore induced in productively infected cells and can be regarded as an innate defense mechanism that eliminates them. HIV-1 replication is reduced but not abolished by this death response $[1,9]$.

2. Estaquier et al. cite previous reports concerning the role of DNA-PK in lentiviral replication and suggest that this enzyme may have a protective role against cytotoxic effects exerted by high MOI infections.

Response: Previous studies used transformed cell lines rather than primary $\mathrm{T}$ cells, and lentiviral vectors rather than replication-competent virus. In our report, we examined the roles of DNA-PK in a physiological context using low MOI infections of a replication-competent HIV-1 in activated primary CD4 T cells, the relevant HIV-1 cell target. Also, the previous studies used a knockout approach, whereas we used highly specific pharmacological inhibitors of this kinase. Because DNA-PK has additional, non-catalytic roles in DNA damage repair [10], knockdown may exert effects on cells not observed with the chemical drug, which only inhibits the catalytic kinase activity. Our findings are consistent with growing evidence that DNA-PK plays a role in 
cell death induction under a range of physiological conditions [10-12]. Notably, CD4 T-cell activation, which is strongly associated with HIV-induced CD4 lymphocyte depletion in vivo [13], promotes nuclear translocation and activation of DNA-PK [14], providing further support for its proapoptotic function during HIV-1 infection.

3. The authors question whether our findings are relevant to lentiviral infection in vivo, given the low frequency of CD4 T cells infected with HIV-1 during chronic infection [15]. They also raise concerns regarding the interpretation of our ex vivo experiments, arguing the proportion of cell death observed in these experiments seemed too high relative to the CD4 cell counts measured in the patients from which the samples had been received.

Response: The paper did not directly investigate nor make definitive claims regarding in vivo effects, though it generated testable hypotheses that were discussed. The comments from Estaquier therefore go beyond the scope of the paper and are speculative. The potential relevance of the paper is supported by several in vivo studies that have unequivocally demonstrated that during the early, acute stage of SIV infection, 30-60\% of the activated memory CD4 $\mathrm{T}$ cells throughout the body are productively infected and eliminated within days of infection as a result of a direct viral cytopathic effect $[3,16,17]$. Similarly, studies in human subjects have shown that activated CD4 lymphocytes, the major targets for HIV-1 infection, are massively depleted during the acute phase, largely as a result of cytopathic effects associated with productive HIV-1 infection $[13,18-20]$. Our study showing that integration triggers a death signal in the course of productive infection in activated CD4 T cells is consistent with these previous analyses, and it may therefore be relevant to in vivo infection. This relevance is further demonstrated by our ex vivo experiments in which, following cell activation, profound death of CD4 $\mathrm{T}$ cells was observed in samples from untreated HIV-1-infected subjects but not from healthy donors. A substantial proportion of dying cells harbored viral DNA, and cell death was largely alleviated by raltegravir, establishing a causal link between viral integration and cell death ex vivo. Activation sensitizes cells to additional rounds of viral replication and the consequent cell death, providing the likely explanation for the massive death observed ex vivo even in samples taken from patients with a relatively high CD4 T cell count. Additional mechanisms such as activation-induced cell death and CTL-mediated cytotoxicity may have contributed to activated
CD4 T cell depletion ex vivo, because cell death was not completely blocked by the antiretroviral drugs and not all dying cells harbored viral DNA. Collectively, we suggest that the mechanism described in our study drives loss of activated CD4 lymphocytes productively infected with HIV-1, and additional mechanisms may contribute to CD4 depletion of uninfected as well as abortively infected cells [21-23].

4. Estaquier et al. suggest that our study claims that every cell integrating viral DNA automatically dies and suggest that such model would be inconsistent with non-pathogenic SIV infection, in which less cell death has been documented despite sustained viral replication.

Response: We do not suggest that every cell dies after infection. In fact, our data suggests that only activated $\mathrm{T}$ cells are susceptible to this mechanism of cytolysis, a central theme of the paper. The question of pathogenic versus non-pathogenic SIV infections is beyond the scope of our study, as we have not experimentally addressed them. Nevertheless, massive depletion of CD4 lymphocytes from the gastrointestinal tract was reported during the acute phase of both pathogenic and non-pathogenic SIV infections, suggesting that in both cases target cells are susceptible to direct lysis by the virus [24]. Cell death by the mechanism described in our study is therefore not inconsistent with non-pathogenic SIV infections in vivo. We agree with the authors that non-pathogenic SIV infections are associated with lower activation of CD4 lymphocytes, potentially providing protection from activation-induced cell death [24-26]. Interestingly, nuclear localization and activity of DNA-PK correlate with CD4 T cell activation and are regulated during the cell cycle $[14,27]$. These studies therefore suggest that proviral DNA integration does not automatically lead to cell death and that the cytopathic effects triggered by viral integration may also be mitigated in the course of non-pathogenic SIV infection.

Competing interests

The authors declare that they have no competing interests.

\begin{abstract}
Author details
'Virology Laboratory, Vaccine Research Center, National Institute for Allergy and Infectious Diseases, National Institutes of Health, Bldg. 40, Room 4502, MSC-3005, 40 Convent Drive, Bethesda, MD 20892-3005, USA. 'Immunology Laboratory, Vaccine Research Center, National Institute for Allergy and Infectious Diseases, National Institutes of Health, Bldg. 40, Room 4502, MSC-3005, 40 Convent Drive, Bethesda, MD 20892-3005, USA. ${ }^{3}$ Current address: Sanofi, 640 Memorial Drive, Cambridge, MA 02139, USA.
\end{abstract}

Received: 8 November 2013 Accepted: 11 November 2013 Published: 9 December 2013 


\section{References}

1. Cooper A, Garcia M, Petrovas C, Yamamoto T, Koup RA, Nabel GJ: HIV-1 causes CD4 cell death through DNA-dependent protein kinase during viral integration. Nature 2013, 498:376-379.

2. Ho DD, Neumann AU, Perelson AS, Chen W, Leonard JM, Markowitz M: Rapid turnover of plasma virions and CD4 lymphocytes in HIV-1 infection. Nature 1995, 373:123-126.

3. Mattapallil JJ, Douek DC, Hill B, Nishimura Y, Martin M, Roederer M: Massive infection and loss of memory CD4+ T cells in multiple tissues during acute SIV infection. Nature 2005, 434:1093-1097.

4. Butler SL, Hansen MS, Bushman FD: A quantitative assay for HIV DNA integration in vivo. Nat Med 2001, 7:631-634.

5. Vatakis DN, Nixon CC, Bristol G, Zack JA: Differentially stimulated CD4+ T cells display altered human immunodeficiency virus infection kinetics: implications for the efficacy of antiviral agents. J Virol 2009, 83:3374-3378.

6. Gekonge B, Raymond AD, Yin X, Kostman J, Mounzer K, Collman RG, Showe L, Montaner $\sqcup$ : Retinoblastoma protein induction by HIV viremia or CCR5 in monocytes exposed to HIV-1 mediates protection from activation-induced apoptosis: ex vivo and in vitro study. J Leukoc Biol 2012, 92:397-405.

7. Geleziunas R, Xu W, Takeda K, Ichijo H, Greene WC: HIV-1 Nef inhibits ASK1-dependent death signalling providing a potential mechanism for protecting the infected host cell. Nature 2001, 410:834-838.

8. Riss TL, Moravec RA: Use of multiple assay endpoints to investigate the effects of incubation time, dose of toxin, and plating density in cell-based cytotoxicity assays. Assay Drug Dev Technol 2004, 2:51-62.

9. Chinnaiyan AM, Woffendin C, Dixit VM, Nabel GJ: The inhibition of pro-apoptotic ICE-like proteases enhances HIV replication. Nat Med 1997, 3:333-337.

10. Callen E, Jankovic M, Wong N, Zha S, Chen HT, Difilippantonio S, Di Virgilio M, Heidkamp G, Alt FW, Nussenzweig A, Nussenzweig M: Essential role for DNAPKcs in DNA double-strand break repair and apoptosis in ATM-deficient lymphocytes. Mol Cell 2009, 34:285-297.

11. Hill R, Lee PW: The DNA-dependent protein kinase (DNA-PK): more than just a case of making ends meet? Cell Cycle 2010, 9:3460-3469.

12. Shao L, Goronzy JJ, Weyand CM: DNA-dependent protein kinase catalytic subunit mediates T-cell loss in rheumatoid arthritis. EMBO Mol Med 2010 2:415-427.

13. Brenchley JM, Schacker TW, Ruff LE, Price DA, Taylor JH, Beilman GJ, Nguyen PL Khoruts A, Larson M, Haase AT, Douek DC: CD4+ T cell depletion during all stages of HIV disease occurs predominantly in the gastrointestinal tract. J Exp Med 2004, 200:749-759.

14. Nagasawa M, Watanabe F, Suwa A, Yamamoto K, Tsukada K, Teraoka H: Nuclear translocation of the catalytic component of DNA-dependent protein kinase upon growth stimulation in normal human $\mathrm{T}$ lymphocytes. Cell Struct Funct 1997, 22:585-594.

15. Haase AT: Population biology of HIV-1 infection: viral and CD4+ T cell demographics and dynamics in lymphatic tissues. Annu Rev Immunol 1999, 17:625-656.

16. Veazey RS, DeMaria M, Chalifoux LV, Shvetz DE, Pauley DR, Knight HL, Rosenzweig M, Johnson RP, Desrosiers RC, Lackner AA: Gastrointestinal tract as a major site of CD4+ T cell depletion and viral replication in SIV infection. Science 1998, 280:427-431.

17. Veazey RS, Tham IC, Mansfield KG, DeMaria M, Forand AE, Shvetz DE, Chalifoux LV, Sehgal PK, Lackner AA: Identifying the target cell in primary simian immunodeficiency virus (SIV) infection: highly activated memory CD4(+) T cells are rapidly eliminated in early SIV infection in vivo. J Virol 2000, 74:57-64.

18. Guadalupe M, Reay E, Sankaran S, Prindiville T, Flamm J, McNeil A, Dandekar S: Severe CD4+ T-cell depletion in gut lymphoid tissue during primary human immunodeficiency virus type 1 infection and substantial delay in restoration following highly active antiretroviral therapy. J Virol 2003, 77:11708-11717.

19. Mehandru S, Poles MA, Tenner-Racz K, Horowitz A, Hurley A, Hogan C, Boden D, Racz P, Markowitz M: Primary HIV-1 infection is associated with preferential depletion of CD4+ T lymphocytes from effector sites in the gastrointestinal tract. J Exp Med 2004, 200:761-770.

20. Mehandru S, Poles MA, Tenner-Racz K, Manuelli V, Jean-Pierre P, Lopez P, Shet A, Low A, Mohri H, Boden D, Racz P, Markowitz M: Mechanisms of gastrointestinal CD4+ T-cell depletion during acute and early human immunodeficiency virus type 1 infection. J Virol 2007, 81:599-612.
21. Hazenberg MD, Hamann D, Schuitemaker H, Miedema F: T cell depletion in HIV-1 infection: how CD4+ T cells go out of stock. Nat Immunol 2000, 1:285-289

22. Doitsh G, Cavrois M, Lassen KG, Zepeda O, Yang Z, Santiago ML, Hebbeler AM, Greene WC: Abortive HIV infection mediates CD4 T cell depletion and inflammation in human lymphoid tissue. Cell 2010, 143:789-801.

23. Li L, Olvera JM, Yoder KE, Mitchell RS, Butler SL, Lieber M, Martin SL, Bushman FD: Role of the non-homologous DNA end joining pathway in the early steps of retroviral infection. EMBO J 2001, 20:3272-3281.

24. Pandrea IV, Gautam R, Ribeiro RM, Brenchley JM, Butler IF, Pattison M, Rasmussen T, Marx PA, Silvestri G, Lackner AA, Perelson AS, Douek DC, Veazey RS, Apetrei C: Acute loss of intestinal CD4+ T cells is not predictive of simian immunodeficiency virus virulence. J Immunol 2007, 179:3035-3046.

25. Cumont MC, Diop O, Vaslin B, Elbim C, Viollet L, Monceaux V, Lay S, Silvestri G, Le Grand R, Muller-Trutwin M, Hurtrel B, Estaquier J: Early divergence in lymphoid tissue apoptosis between pathogenic and nonpathogenic simian immunodeficiency virus infections of nonhuman primates. J Virol 2008, 82:1175-1184.

26. Paiardini M, Cervasi B, Reyes-Aviles E, Micci L, Ortiz AM, Chahroudi A, Vinton C, Gordon SN, Bosinger SE, Francella N, Hallberg PL, Cramer E, Schlub T, Chan ML, Riddick NE, Collman RG, Apetrei C, Pandrea I, Else J, Munch J, Kirchhoff F, Davenport MP, Brenchley JM, Silvestri G: Low levels of SIV infection in sooty mangabey central memory $\mathrm{CD}(4)(+) \mathrm{T}$ cells are associated with limited CCR5 expression. Nat Med 2011, 17:830-836.

27. Chen BP, Chan DW, Kobayashi J, Burma S, Asaithamby A, Morotomi-Yano K Botvinick E, Qin J, Chen DJ: Cell cycle dependence of DNA-dependent protein kinase phosphorylation in response to DNA double strand breaks. J Biol Chem 2005, 280:14709-14715.

doi:10.1186/1742-4690-10-150

Cite this article as: Cooper et al:: HIV integration and T cell death: additional commentary. Retrovirology 2013 10:150.

\section{Submit your next manuscript to BioMed Central and take full advantage of:}

- Convenient online submission

- Thorough peer review

- No space constraints or color figure charges

- Immediate publication on acceptance

- Inclusion in PubMed, CAS, Scopus and Google Scholar

- Research which is freely available for redistribution 